\title{
Border Justice: Migration and Accountability for Human Rights Violations
}

\author{
Cathryn Costello* and Itamar Mann ${ }^{* *}$
}

(Received 03 March 2020; accepted 03 March 2020)

\begin{abstract}
This introductory Article sets out the premise of the Special Issue, the entrenched and pervasive nature of human rights violations in the context of migration control and the apparent lack of accountability for such violations. It sets out features of contemporary migration control practices and their legal governance that contribute to this phenomenon, namely the exceptional treatment of migration in international law; the limited scope of international refugee law; and the pervasive use of externalized, delegated migration controls, in particular by the EU and its Member States. The roots of the current condition are traced back to the containment practices that emerged at the end of the Cold War, with the 2015 "crisis" framed both as an illustration of the failures of containment, and a source of further stasis. Following an overview of the contributions that make up the Special Issue, this Article identifies five emergent themes, and suggests further lines of inquiry. These are: the promise and limits of strategic human rights limitations; the role of both international criminal law, and domestic (and regional) tort law in securing accountability; the turn to positive obligations to challenge entrenched features of containment; and the role of direct action in support of and solidarity with those challenging migration controls most directly, refugees and migrants themselves. Rather than offering panaceas, the Article concludes with the identification of further new challenges, notably the role of new technologies in further dissipating lines of accountability for decisions to exclude.
\end{abstract}

Keywords: Migration; refugees; litigation; human rights; International law

This Special Issue was prompted by a dual concern: On the one hand, we believed that accountability for human rights violations in the context of migration control is often insufficient, or lacking entirely; on the other hand, we observed that the mechanisms that may provide such accountability are poorly understood. Was the latter observation the reason for the former one? At the very least, in order to identify clearly the most serious accountability gaps, a cross-cutting study was apt. Such a study would aim to examine and integrate various legal disciplines, including international law, EU law, and domestic law. It would also try to capture a wide set of geographical contexts, with the caveat of also having an avowedly EU-centric view of things; for scholars working in and around the European space, there seemed to be some justification for such a focus.

The present special issue brings together authors who have all previously offered important contributions to the burgeoning field of global migration law, ${ }^{1}$ and follows an initial workshop

\footnotetext{
${ }^{*}$ Andrew Mellon Professor of Refugee and Migration Law, Refugee Studies Centre, Oxford; Principal Investigator on ERC Grant RefMig, Grant Agreement 716968, which supported work on this Special Issue.

${ }^{* *}$ Senior lecturer, the University of Haifa, Faculty of Law and principal investigator, the Minerva Center for the Rule of Law in Extreme Conditions.

${ }^{1}$ On "global migration law," see Jaya Ramji-Nogales, Moving Beyond the Refugee Law Paradigm, 111 AJIL UNBOUND 8 (2017); Peter Spiro, The Possibilities of Global Migration Law, 111 AJIL Unbound 3 (2017).
} 
hosted by the Refugee Studies Centre at the University of Oxford in November 2018, supported by the RefMig ERC project. We would first like to express deep gratitude to the German Law Journal for offering such an appropriate forum for publication. Professor Nora Markard, editor at the journal, has shaped the Special Issue profoundly, offering incisive and insightful comments on the contributions.

Readers will not be surprised by the observation that many human rights violations occur in the context of migration control. Some of these are evident and egregious-beatings of irregular migrants by state security services and private militias; arbitrary deprivation of liberty in inhuman and degrading conditions; deliberate family separation; detention and other mistreatment of children. But many aspects of migration control generate mundane violations that proceed far from any public attention. ${ }^{2}$ For example, visa decisions tend to be opaque, and if applicants are rejected on discriminatory grounds, that may not be evident or easy to prove. Family reunification rights often exist on paper, but in practice are rendered inaccessible by procedural and financial hurdles. ${ }^{3}$ In some instances, the perpetrators of more egregious acts may be answerable before domestic and international courts. Yet, even in Europe, a self-styled beacon of human rights, access to justice to establish accountability for such human rights violations is often practically impossible. And in some instances, even when multiple courts are accessed - think of a rejected asylum-seeker who applies to an international court or human rights body to contest her removal—human rights violations may still go unchecked. Less visible and more mundane violations also may escape effective judicial or other forms of accountability, but they are often far from trivial, and their cumulative impact may be immense.

The collective study focuses on the practices of the EU and its Member States, and of other states in the "Global North" that engage in externalized migration control. These states have long-standing modes of sharing restrictive policies and practices, ${ }^{4}$ many of which are custom built to evade accountability. European practices in particular have been widely mimicked, ${ }^{5}$ although some policies that have been legally normalized in Europe have been successfully constitutionally challenged elsewhere. ${ }^{6}$ The Special Issue also examines EU practices, in particular those of FRONTEX ${ }^{7}$ and EASO. ${ }^{8}$ Two contributions in particular highlight poignantly that, while all EU agencies and bodies are bound to respect the EU Charter of Fundamental Rights ${ }^{9}$ (Article 51(1) EUCFR), and the EU is purportedly as a "community based on the rule of law," accountability gaps are hard-wired into these EU bodies.

Our sense that there is a lack of accountability is shared by human rights experts. Recent reports by both the UN Special Rapporteur on torture ${ }^{10}$ and the Rapporteur on extrajudicial, summary or arbitrary executions ${ }^{11}$ highlight serious accountability gaps. The latter characterized

\footnotetext{
${ }^{2} C f$. comparison between "banal" and "spectacular" violations of migrant and refuge rights, in Ioannis Kalpouzos \& Itamar Mann, Banal Crimes Against Humanity: The Case of Asylum Seekers in Greece, 16(2) MELb. J. INT'L. L. 1 (2015).

${ }^{3}$ Cathry Costello, Kees Groenendijk \& Louise Halleskov StorgaArd, Realising the Right to Family Reunification of Refugees in Europe (2017).

${ }^{4}$ Daniel Ghezelbash, Refuge Lost: Asylum Law in an Interdependent World (2018); David Scott Fitzgerald, Refuge beyond Reach: How Rich Democracies Repel Asylum Seekers 52-53 (2019).

${ }^{5}$ Helene Lambert, Jane Mcadam \& Maryellen Fullerton, The Global Reach of European Refugee Law (2014).

${ }^{6} \mathrm{See}$, for instance, on the successful Canadian constitutional challenge to "Safe Country of Origin" practices in asylum law Cathryn Costello, Safe Country? Says Who?, 28(4) INT'L J. Refugee L. 601 (2016).

${ }^{7}$ See generally Melanie Fink, Frontex and Human Rights: Responsibility in “Multi-Actor Situations” under the ECHR and EU Public Liability Law, 180-316 (2018); Roberta Mungianu, Frontex and Non-Refoulement: The INTERNATIONAL RESPONSIBILITY OF THE EU (2016).

${ }^{8}$ Evangelia (Lilian) Tsourdi, Bottom-up Salvation? From Practical Cooperation Towards Joint Implementation Through the European Asylum Support Office, 1 EUROPEAN PAPERS 997 (2016).

${ }^{9}$ Charter of Fundamental Rights of the European Union, 2012 O.J. (C 326) 391 [hereinafter EUCFR].

${ }^{10}$ Nils Melzer, Report of the Special Rapporteur on Torture and Other Cruel, Inhuman or Degrading Treatment or Punishment, U.N. Doc. A/72/335 (Feb. 26, 2018).

${ }^{11}$ Agnes Callamard (Special Rapporteur of the Human Rights Council on Extrajudicial, Summary or Arbitrary Executions), Unlawful Death of Refugees and Migrants, U.N. Doc. A/72/335 (Aug. 15, 2017).
} 
current migration control practices as an "international regime of impunity" regarding migrant deaths. The language harks back to struggles against impunity, historically formulated against the backdrop of authoritarianism. ${ }^{12}$ The underlying assumption, which we share, is that when it comes to migrants and refugees, legal safeguards for accountability are systemically and globally failing.

Four embedded features of migration control practices arguably render accountability elusive. These features are inscribed in the various legal systems under consideration, to varying degrees, reflecting the institutionalization of bordered sovereign states as central to modern international law. They also need to be understood against the backdrop of global inequalities, which offer greater mobility for capital than workers, and more mobility and migration opportunities to the already privileged than those in greatest need.

(1) There is an in-built limitation to how human rights law treats migration control, given the asymmetry in international law between the right to leave any country and the right to enter. While the former is part of the international bill of rights (albeit poorly understood and implemented $\left.{ }^{13}\right)$, the latter is generally treated as an exception to states' migration control prerogatives. As a result, it is both doctrinally and practically easier to challenge decisions to deport than refusals of entry, particularly if these are taken at a distance. ${ }^{14}$ Furthermore, international human rights courts often interpret human rights norms in a manner that permits greater leeway for rights restrictions, including detention, than in other contexts. While different human rights systems take different views of this matter, ${ }^{15}$ the statist migration control assumption dilutes human rights in many migration-related contexts.

(2) Against this backdrop, the legal category of refugee is problematic. While all states have obligations not to refoule a wider category of persons, many states have particular obligations to those defined as refugees in international treaties. These commitments are also part of EU law. However, for many ethicists, the refugee definition is too narrow, and ought to be expanded or reinterpreted to cover those fleeing a wider range of threats. ${ }^{16}$ They question whether it is ethical to create a privileged category of migrant, the refugee. Irrespective of one's position on that matter, there is a further gap in protection-the failure to recognize refugees as such in the asylum procedures, notwithstanding the declaratory character of refugee status. There is a growing body of empirical scholarship on deficits in asylum decision-making, leading to arbitrary variations in recognition, the rejection of strong claims and the creation of a population in need of protection who are stigmatized as "failed asylum-seekers." 17

(3) Given that migration control is increasingly extraterritorial, the putative jurisdictional limits of human rights obligations are a stumbling block to accountability. ${ }^{18}$ Most human

\footnotetext{
${ }^{12}$ Itamar Mann, The New Anti-Impunity: Border Violence as Crime (U. PENN. J. INT'L L., forthcoming, on file with the authors).

${ }^{13}$ For a rare example of insightful recent scholarship on the right, see Nora Markard, The Right to Leave by Sea: Legal Limits on EU Migration Control by Third Countries, 27 EUR. J. INT'L L. 591 (2016).

${ }^{14} \mathrm{On}$ the creation of distance as central to the accountability gap concerning migrants, see Ioannis Kalpouzos, International Criminal Law and the Violence against Migrants, in this issue.

${ }^{15}$ Marie-Bénédicte Dembour, When Humans Become Migrants - Study of the European Court of Human RightS WITH AN INTER-AMERICAN COUNTERPOINT (2015).

${ }^{16}$ For example, Andrew Shacknove, Who is a Refugee?, 95(2) Ethics 274 (1985); Matthew Gibney, The EthiCs AND Politics of Asylum: Liberal Democracy and the Response to Refugees (2004); Alexander Betts, Survival Migration: Failed Governance and the Crisis of Displacement (2013). Cf. Max Cherem, Refugee Rights: Against Expanding the Definition of a "Refugee" and Unilateral Protection Elsewhere, 24(2) J. POL. PHIL. 183 (2016).

${ }^{17}$ Literature on problematic variation in recognition rates includes: Jaya Ramji-Nogales, Andrew I. Schoenholtz \& Philip G. Schrag, Refugee Roulette: Disparities in Asylum Adjudication, 60 Stan. L. Rev. 295 (2007-2008); RebecCA Hamlin, Let Me Be a Refugee: Administrative Justice and the Politics of Asylum in the United States, Canada, and Australia (2014); Hilary Evans-Cameron, Refugee Law's Fact-Finding Crisis: Truth, Risk, and the Wrong Mistake (2018).

${ }^{18}$ See further MaArten den Heijer, Europe and Extraterritorial Asylum (2012); Thomas Gammeltoft-Hansen, Access to Asylum: International Refugee Law and the Globalisation of Migration Control (2011); Violeta
} 
rights treaties obligate states to protect rights within their "jurisdiction," a definition that is constantly contested. ${ }^{19}$ To be sure, not all human rights instruments are so limited. For instance, the EU Charter of Fundamental Rights has no such limitation. ${ }^{20}$ A territorial conception of human rights not only limits accountability for actions "abroad," but explains, at least in part, why migration control has been de-territorialized.

(4) Migration control is a shared endeavor, involving many states and actors. Where many states cooperate, complex legal questions of shared responsibility emerge. ${ }^{21}$ In addition, States often engage international organizations, including UNHCR and IOM, in the containment of migrants and refugees outside their territories. ${ }^{22}$ Relatedly, migration control is often outsourced to private actors, raising questions about the responsibility of states, as well as the private actors' own human rights obligations. Private actors process visa applications, enforce visa requirements as "carriers," and more. ${ }^{23}$ As one contributor argues, private security companies in particular may have a key role as possible levers for accountability. ${ }^{24}$

Migration control occurs against the backdrop of a global economic order that has facilitated global flows of capital, goods and services, but rarely of human beings as such. ${ }^{25}$ As a result, many would-be entrants have been deflected into irregularity. While the content of the "neoliberal condition" is contested, it has generally been characterized by a restrictive trend regarding settlement migration and the resurgence of selective forms of temporary migration, alongside greater

Moreno-lax, Accessing Asylum in Europe: Extraterritorial Border Controls and Refugee Rights Under EU LAW (2017).

${ }^{19}$ Marko Milanovic, Extraterritorial Application of Human Rights Treaties: Law, Principles, and Policy (2011); Samantha Besson, The Extraterritoriality of the European Convention on Human Rights: Why Human Rights Depend on Jurisdiction and What Jurisdiction Amounts to, 25 LEIDEN J. INT'L L. 857 (2012); Maarten den Heijer, The Practice of Shared Responsibility in Relation to Refoulement, in THE PRACTICE OF SHARED RESPONSIBILITY IN INTERNATIONAL LAW (André Nollkaemper \& Ilias Plakokefalos eds., 2016); Miles Jackson, Freeing Soering: The ECHR, State Complicity in Torture and Jurisdiction, 27(3) Eur. J. InT'L L. 817 (2016); ItAmar Mann, Humanity AT Sea: Maritime Migration and the Foundations of International LaW (2016).

${ }^{20}$ Violeta Moreno-Lax \& Cathryn Costello, The Extraterritorial Application of the EU Charter of Fundamental Rights: From Territoriality to Facticity, the Effectiveness Model, in The EU Charter of Fundamental Rights - A Commentary (Steve Peers, Tamara Hervey, Jeff Kenner \& Angela Ward eds., 2014).

${ }^{21}$ André Nollkaemper, Shared Responsibility for Human Rights Violations: A Relational Account, in HUMAN RiGHTS AND the Dark Side of Globalisation: Transnational law Enforcement and Migration Control 27 (Thomas Gammeltoft-Hansen \& Jens Vedsted-Hansen eds., 2016).

${ }^{22}$ Anne Koch, The Politics and Discourse of Migrant Return: The Role of UNHCR and IOM in the Governance of Return, 40(6) Journal of Ethnic and Migration Studies 905 (2014); BERgTORA SANDViK \& Lindskov JaCOBSEN, UNHCR AND the Struggle for Accountability - Technology, law and Results-Based Management (2016); Carla Ferstman, International Organizations and the Fight For AcCountability: The Remedies and Reparations Gap (2017); Asher L. Hirsch \& Cameron Doig, Outsourcing Control: The International Organization for Migration in Indonesia, 22(5) I.J.H.R. 681 (2018); Guglielmo Verdirame, The UN and Human Rights: Who Guards the Guardians? (2011).

${ }^{23}$ Gammeltoft-Hansen, supra note 18; Georg Menz, Neo-Liberalism, Privatization and the Outsourcing of Migration Management: A Five-Country Comparison, 15(2) Competition AND Change 116 (2011); Thomas GammeltoftHansen \& Ninna Nyberg Sørensen, The Migration Industry and the Commercialization of International Migration (2013); Tilman Rodenhäuser, Another Brick in the Wall: Carrier Sanctions and the Privatization of Immigration Control, 26 INT'L J. RefugeE L. 223 (2014); Tendayi Bloom, The Business of Migration Control: Delegating Migration Control Functions to Private Actors, 6(2) Global Policy 151 (2015); Markos Karavias, Shared Responsibility and Multinational Enterprises, 62 N.I.L.R. 91 (2015); Sophie SCHOlten, The Privatisation of Immigration Control through Carrier Sanctions: The Role of Private Transport Companies in Dutch and British Immigration Control (2015); Matthew B. Flynn, Capitalism and Immigration Control: What Political Economy Reveals about the Global Spread of Detention, in Challenging Immigration Detention (Michael J. Flynn \& Matthew B. Flynn eds., 2017); Daria Davitti, Biopolitical Borders and the State of Exception in the European Migration “Crisis," 29 EUR. J. INT'L L. 1173 (2018).

${ }^{24}$ Daria Davitti, Beyond the Governance Gap: Accountability in Privatized Migration Control, in this issue.

${ }^{25}$ See generally, Quinn Slobodian, Globalists: The End of EMPIRE AND THE BirTh of NeOliberalism (2018). 
freedom for capital leading to globalized production and value chains. The resulting global inequality of mobility and migration opportunities stratifies people along lines of class, race, gender, and, most obviously, country of origin. ${ }^{26}$ Meanwhile, many of those in greatest need of migration opportunities - refugees fleeing and the poor seeking a decent life-are effectively shut out from licit mobility and migration. The result is not less migration, but often more migration in precarious conditions - even for the few who manage to find legal migration opportunities -with migrants bearing endemic risks of labor market exploitation and abuse, precisely due to their legal predicament. ${ }^{27}$ The Special Issue focuses on non-refoulement, and the right to life, an admittedly narrow lens from which to survey the impact of migration control and migration status on human rights, but an appropriate one for this venture. ${ }^{28}$

The Special Issue brings together legal scholars to reflect on the state of the art in international and EU law, when it comes to accountability for violations of migrant rights. Each of the authors has an answer, implicit or explicit, to the twin questions above: Where do accountability gaps lie? And what have we misunderstood so far about the relevant law? The authors bring to their inquiries different methodological perspectives, including doctrinal interventions; inquiries in law and society; works informed by advocate and activist experiences; and theoretical analyses. In contrast to the existing scholarship on accountability in migration, this Special Issue looks to and also beyond international human rights law, to examine different forms of legal accountability.

Concerning international human rights law, contributors examine both settled norms such as non-refoulement, and less definitive areas such as the positive duties deriving from the right to life. Positive obligations to avoid violations, particularly due diligence duties, indeed emerge from the volume as key doctrinal frameworks for closing the accountability deficit. Contributors also re-examine the concept of "jurisdiction" in international human rights law. Furthermore, we sought to examine the turn to International Criminal Law to frame the rights violations in the context of migration control. This framing suggests we are no longer "just" dealing with human rights violations, but that the systematic and serious character of the acts in question calls for their examination as international crimes. Previous scholarship in this vein includes Vincent Chetail's work on the international crime of deportation, examining whether routine migration control and international crime may not sometimes be one and the same. ${ }^{29}$ Scholars and lawyers have sought to frame aspects of migration control as crimes against humanity in particular, such as the Greek immigration detention system, ${ }^{30}$ Australian offshore detention, ${ }^{31}$ as well as the EU's complicity in deaths as sea. ${ }^{32}$

\footnotetext{
${ }^{26}$ For a general critique, see Ayelet Shachar, The Birthright Lottery: Citizenship and Global Inequality (2009).

${ }^{27}$ Cathryn Costello, Migrants and Forced Labour: A Labour Law Response, in The Autonomy of LABOUR LAW ch 8, 189-227 (Alan Bogg, Cathryn Costello, ACL Davies \& Jeremias Prassl eds., 2014).

${ }^{28}$ There is a wider research agenda concerning how migration and migration control are linked to violations of human rights at work. See further, Mark Freedland \& Cathryn Costello, Migrants at Work and the Division of Labour Law, in Migrants at Work: Immigration and Vulnerability in Labour Law (Cathryn Costello \& Mark Freedland eds., 2014). Cathryn Costello, EU Migration and Asylum Law: A Labour Law / Workers' Rights Perspective, in EDWARD ELGAR Research Handbook on EU Labour LaW (Alan Bogg, Cathryn Costello \& ACL Davies eds., 2016). A focus on labor rights also brings the ILO into the institutional constellation. See for instance the ILO's complaint opened against Qatar for violation of migrant workers' rights: ILO, Complaint concerning Non-Observance by Qatar of the Forced Labour Convention, 1930 (No 29), and the Labour Inspection Convention 1947 (No 81), Made by Delegates to the 103rd Session (2014) of the International Labour Conference under Article 26 of the ILO Constitution, U.N. Doc. GB 326/INS/8.Rev (Mar. 17, 2016).

${ }^{29}$ Vincent Chetail, Is There Any Blood on My Hands? Deportation as a Crime of International Law, 29(3) LEIDEN J. INT'L L. 917 (2016).

${ }^{30}$ Ioannis Kapouzos \& Itamar Mann, Banal Crimes Against Humanity: The Case of Asylum Seekers in Greece, 16 MelB. J. INT'L L. 1 (2015).

${ }^{31}$ The complaint to the International Criminal Court (ICC) on Australia's offshore detention contains a 108-page legal submission from the Global Legal Action Network (GLAN) and the Stanford International Human Rights Clinic.

${ }^{32}$ Omer Shatz \& Juan Branco, Communication to the Office of the Prosecutor of the International Criminal Court Pursuant to Article 15 of the Rome Statute on EU Migration Policies in the Central Mediterranean and Libya (2014-2019) (2019), https:// www.statewatch.org/news/2019/jun/eu-icc-case-EU-Migration-Policies.pdf.
} 
Private law also figures in the Special Issue as a site in which accountability can be sought and contested. Attempts to turn to tort law reflect the aim of holding private actors to account for their role in migration control human rights violations, or indeed to find new routes to challenge states that violate human rights law with impunity.

\section{A. Roots of the Current Condition}

Externalized migration control, one of the main pillars of containment and its accountability deficits, is not new. In 1983, Atle Grahl-Madsen characterized as the "tragedy of the times" its impact on those seeking refuge in Europe. ${ }^{33} \mathrm{He}$ developed an early insight into the practices that spread after the end of the Cold War, which heralded greater freedom for many, but also refugee containment, as B.S. Chimni examined in his seminal contributions. ${ }^{34}$ The externalization of migration controls cuts across public-private lines with the development of carrier sanctions, fines imposed upon transportation companies when they deliver individuals into a state that has not granted them authorization. ${ }^{35}$ This outsourcing of governmental functions to private actors was also a sign of the times, a hallmark of the neoliberal turn. In the simplest terms, European visa policies became deadly when they were backed up with these sanctions: Prior to carrier sanctions, people traveling without proper documentation could board regular planes and ferries and take their chances on arrivalattempting to either enter the states in question clandestinely or seek asylum on arrival. When one tries to identify the roots of the current condition, carrier sanctions figure as a fundamental building block of our current very unequal "global mobility infrastructure."36

The legality and morality of carrier sanctions has been questioned, ${ }^{37}$ with compelling arguments being offered that carriers have a moral obligation to break the law under certain circumstances to offer safe passage. ${ }^{38}$ Relatedly, one may trace how non-refoulement has become part of a moral vocabulary binding not only upon states, but also upon individuals. ${ }^{39}$ Granted, there is a long history of "sanctuary" and "church asylum" to protect refugees in danger of deportation. Yet this tradition came to be central to international law starting from the same period: "When Churches and their congregations confer 'sanctuary,"' wrote Richard Falk back in 1987, "they are interposing their bodies and lives between the government and these beleaguered individuals from overseas." ${ }^{0}$ There is now a growing body of scholarship on the ethical obligation to disobey unjust migration laws and civil disobedience as an appropriate response to migration control, ${ }^{41}$ a topic to which Itamar Mann returns in this Special Issue.

\footnotetext{
33"It is part of the tragedy of our times that several states by various methods are seeking to prevent or at least to discourage refugees from reaching their shores to seek sanctuary.” ATLE GRAHL-MADSEN, IDENTIFYING THE WORLD's REFUGEES (1983).

${ }^{34}$ B. S. Chimni, The Geopolitics of Refugee Studies: A View from the South, 11(4) J.R.S. 350 (1998).

${ }^{35}$ Council Directive 2001/51 Supplementing the Provisions of Article 26 of the Convention Implementing the Schengen Agreement, 2001 O.J. (L 187); Council Directive 2004/82 on the Obligation of Carriers to Communicate Passenger Data (2004) O.J. (L 261).

${ }^{36}$ Thomas Spijkerboer's apt term; Thomas Spijkerboer, The Global Mobility Infrastructure: Reconceptualising the Externalisation of Migration Control, 20 EuR. J. MigRATION \& L. 452 (2018).

${ }^{37}$ Tendayi Bloom \& Verena Risse, Examining Hidden Coercion at State Borders: Why Carrier Sanctions Cannot Be Justified, 7(2) Ethics \& Global Politics 65 (2014); Tally Kritzman-Amir, Privatization and Delegation of State Authority in Asylum Systems, 5(1) LaW And Ethics of Human Rights 194, 203 (2011).

${ }^{38}$ Theodore Baird \& Thomas Spijkerboer, Carrier Sanctions and the Conflicting Legal Obligations of Carriers: Addressing Human Rights Leakage, 11 AMSTERDAM L. REV. 4 (2019).

${ }^{39}$ For an account of the place of moral imperatives towards migrants and refugees in international law, see Mann, supra note 19. See also Moritz Baumgärtel, Demanding Rights: Europe's Supranational Courts and the Dilemma of Migrant VulNERABILITY (2019) (especially chapter 7 on "Migrant Rights as Existential Commitments").

${ }^{40}$ Richard Falk, Accountability, Asylum, and Sanctuary: Challenging our Political and Legal Imagination, 16 DENV. J. INT'L L. \& POL'y 199, 201 (1988).

${ }^{41}$ Frédéric Mégret, Civil Disobedience and International Law: Sketch for a Theoretical Argument, 46 CAN. Y.B.I.L. 143 (2009); Javier S. Hidalgo, Unjust Borders: Individuals and the Ethics of IMmigration (2019).
} 
European externalized migration controls emerged along with the first Schengen Agreement, signed in June 1985. In the EU legal imaginary, tighter external controls have since been cast as necessary for internal free movement, a framing open to empirical and ethical critique. With that move, the world's most stunning example of constitutionalized internal free movement for persons took a statist turn, which would later be manifested in EU citizenships' derivative character, being a status only for those already holding nationality of the Member States. As the EU developed a common visa policy for at least some categories of entrants, its effect was to tighten up external borders. Indeed, the edifice of what some dub "Fortress Europe" was always more about selective exclusion, rather than an impenetrable fortress. ${ }^{42}$ After all, Member States, for the most part, remain free to allow whomever they wish to live in their territories. Yet, the restrictive dynamics on the "unwanted" were clear. In some instances, those deflected into irregularity were circular seasonal migrants-for instance, Moroccans who had frequently worked in Spain. ${ }^{43}$ But more particularly, those from countries deemed "refugee producing" found themselves deprived of opportunities to travel lawfully. Overall, most migration is legal, but some individuals are effectively shut out of legal migration opportunities, in particular those deemed likely to claim asylum in Europe. ${ }^{44}$

Closely related, of course, was the Dublin system. Originally cast as a mechanism to avoid "refugees in orbit" and clarify responsibility for processing claims, it has developed into a mechanism to contain asylum-seekers and indeed recognized refugees, even once in the EU. The framework, which remains with us today, is widely assumed to require the first EU country where an asylum seeker arrives to process their asylum application. In fact, its rules are more complex, but the basic logic seeks to contain any asylum-seekers who have been admitted at the periphery. The Dublin system emerged in tandem with another important legal innovation-the "Safe Third Country" (STC) practices. Dublin purports to allow all participating states to treat each other as "safe" for asylum-seekers, and in turn STC practices further externalize that presumption. The logic of "protection elsewhere" and "presumptions of safety" are shared. So, for most EU Member States, regarding Italy and Greece as safe for asylum seekers is key to what Noll writing decades ago dubbed "the common market of deflection" (just as Italy and Greece, as well as the rest of EU governments, rely on such presumptions regarding Libya and Turkey). ${ }^{45}$ It has been national courts and the ECtHR that have effectively checked these presumptions, and set human rights conditions for the transfer of asylum-seekers back to "unsafe" states. ${ }^{46}$ However, while courts are generally adept at placing some checks on such deportations in individual cases, they have not questioned STC practices in toto.

EU externalization is not only via STC practices. STC unilaterally incorporates third states into the EU asylum system, without their consent. However, in reality, if asylum-seekers and refugees are to be contained, third states' cooperation must be sought, or perhaps, bought. Migration control has thus become a central, perhaps now predominant, element of EU relations with states outside the EU, in particular with Turkey, and states across the Middle East and Africa. From the Cotonou Agreement in 2000, the 2005 "Global Approach to Migration," and onwards to the EU-Turkey 'Deal' and the EU "Trust Fund” for Africa, the EU has offered funds and material

\footnotetext{
${ }^{42}$ Hein de Haas, Katharina Natter \& Simona Vezzoli, Growing Restrictiveness or Changing Selection? The Nature and Evolution of Migration Policies, 52(2) INT'L Migr. ReV. 324 (2018).

${ }^{43}$ See generally Hein de Haas \& Mathias Czaika, The Globalization of Migration: Has the World Become More Migratory?, 48(2) INT'L MigR. Rev. 283 (2014).

${ }^{44} I d$.

${ }^{45}$ Gregor Noll, Negotiating Asylum: The EU Acquis, Extraterritorial Protection and the Common Market of Deflection, 3(3-4) Eur. J. MigR. L. 475 (2001).

${ }^{46}$ M.S.S. v. Belgium and Greece [GC], App. No. 30696/09, http://hudoc.echr.coe.int/eng?i=001-103050; Case C-411/10, N.S. v. Secretary of State for the Home Department and M.E. and Others v. Refugee Applications Commissioner and Minister for Justice, Equality and Law Reform, 2011 E.C.R. I-13905. The CJEU came late to this issue and in N.S. and M.E. appeared to follow the ECtHR, but also sought to allow states to rely on EU obligation of mutual recognition in a manner that was less rights protective than the ECtHR.
} 
support for migration controls, often disbursed through private companies or international organizations, in particular the IOM. The raised political stakes and costs of containment also seem to have rendered it less transparent, further diluting accountability.

It may be worth recalling that while STC and externalization are based on a logic of shifting and deflecting refugees elsewhere, in a functioning global refugee regime, states would not fear "too many" refugees, for the responsibility would be shared: financially, normatively, and in terms of offering refugees choices of states of asylum. It was once thus: In 1956, when 180,000 Hungarians fled to Austria, the international community agreed that Austria was then "overburdened" with refugees, and resettled the Hungarian refugees within months. ${ }^{47}$ The then UN High Commissioner for Refugees, now UN Secretary General, António Guterres, reminded the EU of this history repeatedly in 2015 , but it failed to resonate. ${ }^{48}$

Once travel is illegalized, a range of other restrictions ensue. Although refugees are ostensibly protected from penalization for irregular entry and stay under the Refugee Convention, ${ }^{49}$ in practice irregular entry is treated as a basis for immigration detention, which has often withstood challenges under human rights law, at least provided it is in a suitable place for a limited time. ${ }^{50}$ Criminal law is also increasingly brought to bear. Irregular migrants and refugees are not simply demonized rhetorically as "criminals," many European states have criminalized a range of administrative infractions of immigration law, as well as irregular entry and presence. Alessandro Spena and other criminal law theorists have decried this criminalization as a distortion of criminal law. ${ }^{51}$ Along with the criminalization of irregular migrants has come the criminalization of assistance to them, even when such assistance appears entirely benevolent, sometimes even life-saving. ${ }^{52}$

\section{B. Crisis and Stasis Post-2015}

The events dubbed a "crisis" in 2015 were long in the making. Even before the arrival of large numbers of refugees on the shores of the Greek islands, mass drownings in the Central Mediterranean had been seen to shock the public consciousness. The conflict in Syria had begun four years earlier, and was and is still characterized by massive displacement, principally within Syria, but also with millions fleeing the country. While most Syrians remained in neighboring countries, many defied

\footnotetext{
${ }^{47}$ Within months, only 410 refugees were left in in Austria, with the others having relocated to 36 other states: Argentina (1,020), Australia (11,680), Belgium (5,850), Brazil (1,660), Canada (27,280), Chile (270), Colombia (220), Costa Rica (30), Cuba (5), Cyprus (2), Denmark (1,380), Dominican Republic (580), Ecuador (1), Federation of Rhodesia and Nyasaland (60), France (12,690), Germany (15,470), Iceland (50), Ireland (540), Israel (2,060), Italy (4,090), Luxembourg (240), Netherlands $(3,650)$, New Zealand (1,090), Nicaragua (4), Norway (1,590), Paraguay (7), Portugal (4), Republic of South Africa (1,330), Spain (19), Sweden (7,290), Switzerland (12,870), Turkey (510), United Kingdom (20,990), the United States (40,650), Uruguay (37), and Venezuela (780). Marjoleine Zieck, The 1956 Hungarian Refugee Emergency, an Early and Instructive Case of Resettlement, 5(2) AMSTERDAM LAW FORUM 45 (2013).

${ }^{48}$ Remarks by António Guterres, United Nations High Commissioner for Refugees, Brussels, Sept. 15, 2015, AFET/DROI/ LIBE Committees - Joint Event on Migration "Respecting Human Rights in the Context of Migration Flows in the Mediterranean," http://www.unhcr.org/uk/admin/hcspeeches/55fbbdbf9/european-parliament-afetdroilibe-committees-jointevent-migration-respecting.html.

${ }^{49}$ Convention Relating to the Status of Refugees, April 22, 1954, 189 U.N.T.S. 137, art. 31 [hereinafter Refugee Convention]. See Cathryn Costello, Yulia Ioffe \& Teresa Büchsel, Article 31 of the 1951 Convention Relating to the Status of Refugees, UNHCR Legal and Protection Policy Research Series, PPLA/2017/01 (2017).

${ }^{50}$ Saadi v. U.K., 47 E.H.R.R. 17, para. 129 (2008). See Cathryn Costello, Human Rights and the Elusive Universal Subject: Immigration Detention under International Human Rights and EU Law, 19(1) IND. J. GLOBAL LEGAL STUD. 257 (2012); Cathryn Costello, Immigration Detention: The Grounds Beneath Our Feet, 68(1) CURRENT Legal Problems 143 (2015).

${ }^{51}$ Alessandro Spena, A Just Criminalization of Irregular Immigration: Is It Possible?, 11 CRIMINAL LAW AND PHILOSOPHY 351 (2017); Ana Aliverti, The Wrongs of Unlawful Immigration, 11(2) Criminal LAW AND PHILOsopHy 375 (2017); Cathryn Costello, Victim or Perpetrator? The Criminalised Migrant and the Idea of "Harm" in a Labour Market Context, in Criminality AT Work (Alan Bogg, Jennifer Collins, Mark Freedland \& Jonathan Herring eds., 2020).

${ }^{52}$ Rachel Landry, The "Humanitarian Smuggling" of Refugees: Criminal Offence or Moral Obligation? (RSC Working Paper Series No. 119, 2016).
} 
Europe's containment policies and fled, particularly en masse in 2015. In late 2015, thousands of people arrived from Turkey to the Greek islands in rubber dinghies every day. Many, though by no means all, were from Syria and would go on to be recognized as refugees (or at least offered some legally protective status). ${ }^{53}$ Their mode of arrival guaranteed a "crisis" in terms of humanitarian needs, as thousands of people risked their lives on unstable boats, arrived without belongings, and sought to make it in haste to states likely to offer protection in decent conditions. ${ }^{54}$

The arrivals and onward movement rendered visible that the EU approach to asylum, in particular the Dublin System, was defective. Asylum-seekers in the EU have always overwhelmingly had their claims examined in states like Germany and Sweden, rather than Italy or Greece. ${ }^{55}$ Only the unlikely few were ever sent back under Dublin proceedings. "Always more ruse than reality," as Costello and Mouzourakis have put it, asylum seekers and states always flouted the Dublin system, but that was never headline news before. ${ }^{56}$ Now, states that admitted them were cast as also undermining Dublin, and the question of legality and the rule of law itself became up for grabs. Was welcoming refugees legal, or a breach of the rule of law, the very Rechtsstaat itself? Was keeping Schengen borders "open" a decision to break to law, or the maintenance of the status quo? ${ }^{57}$

For the most part, the events of 2015 prompted political responses that were more of the samemore containment; more funding for externalized migration control and cooperation; more detention and focus on enforcement. While creative attempts to institutionalize shared responsibility across the EU effectively failed, ${ }^{58}$ some new institutional constellations did emerge. The amorphous concept of a "hotspot" materialized, promising efficiency via EU support to examine protection claims swiftly, followed by prompt deportation or swift onward movement. First mentioned in the EU Agenda on Migration, ${ }^{59}$ as Mann wrote, the agenda was "an attempt to square the circle of a commitment to asylum and a commitment to deterrence." 60 The contemporary humanitarian and human rights catastrophe in the Greek hotspots, and the concerns about those in Italy, was largely foreseeable; indeed, it is ingrained in the Agenda's administrative architecture. Aside from "hotspots," the EU's principal response to the "crisis" was the 2016 EU-Turkey "Deal," a political stitch up it would later legally disown, in order to avoid the CJEU's legal scrutiny. ${ }^{61}$ This deal, combined with the hotspot approach, has left disastrous results.

Five years down the line, the terrain of accountability for the violation of human rights in this context is more variegated than ever. We are surely no longer in the managerialist moment, though some officials in Brussels may still pretend that "the hotspot approach" is working. In fact, it created an enormous accountability deficit, touched upon by Lilian Tsourdi in her contribution. ${ }^{62}$ Several

\footnotetext{
${ }^{53}$ See generally UNHCR, Over One Million Sea Arrivals Reach Europe in 2015 (Dec. 30, 2015), https://www.unhcr.org/uk/ news/latest/2015/12/5683d0b56/million-sea-arrivals-reach-europe-2015.html.

${ }^{54}$ For further detail, see Cathryn Costello, Overcoming Refugee Containment and Crisis, 21 German L.J. 17 (2020).

${ }^{55}$ Elspeth Guild, Cathryn Costello \& Violeta Moreno-LaX, Study for the LibE Committee: Implementation of the 2015 Council Decisions Establishing Provisional Measures in the Area of International Protection for the Benefit of Italy and Greece (2017); Cathryn Costello \& Minos Mouzourakis, The CEAS - Where Did It All Go Wrong?, in The European Union as an Area of Freedom, Security and Justice 263-55 (Maria Fletcher, Ester Herlin Karnell \& Claudio Matera eds., 2017); Elspeth Guild, Madeline Garlick \& Violeta Moreno-LaX, Study for the LiBE Committee: Enhancing the Common European Asylum System and Alternatives to Dublin (2015).

${ }^{56}$ Costello \& Mouzourakis, supra note 55, at 263.

${ }^{57}$ See further Anuscheh Farahat \& Nora Markard, Forced Migration Governance: In Search of Sovereignty, 17 GERMAN L.J. 923 (2016).

${ }^{58}$ European Commission, Directorate-General Home Affairs, Study on the Feasibility of Establishing a Mechanism for the Relocation of Beneficiaries of International Protection, JLX/2009/ERFX/PR/1005 (July 2010).

${ }^{59}$ European Commission, A European Agenda on Migration (May 13, 2015), COM(2015) 240 final.

${ }^{60}$ Mann, supra note 19, at 191.

${ }^{61}$ European Council Press Release 144/16, EU-Turkey Statement (Mar. 18, 2016), https://www.consilium.europa.eu/en/ press/press-releases/2016/03/18/eu-turkey-statement/. See Cases T-192/16, T-193/16, and T-257/16, N.F., N.G., and N.M. v. European Council, ECLI:EU:T:2017:128 (Feb. 28, 2018).

${ }^{62}$ Evangelia (Lilian) Tsourdi, Holding the European Asylum Support Office Accountable for Its Role in Asylum DecisionMaking: Mission Impossible?, in this issue.
} 
Aegean islands gradually came to resemble offshore detention facilities familiar from examples further afield such as Manus Island and Nauru. The Greek police is crushing forceful protests on the islands against the construction of detention centers that would finalize this process, generously utilizing tear gas and other anti-riot methods. ${ }^{63}$ As controversial, in 2017, Italy re-established longdefunct cooperative enforcement measures with Libya, under the aegis of EU funding and operational support from Frontex. That so many of our authors have chosen to address the Italy-EULibya nexus signals how glaring is the absence of accountability along the "central Mediterranean migration route."

Much of the response to the "crisis" has been of doubtful legality, or at least in extralegal forms that have evaded legal scrutiny. That is the case thus far with the EU-Turkey Deal itself, and its attendant procedural and substantive impact on the rights of those effectively blocked from accessing protection in Europe. As mentioned, the Court of Justice of the European Union (CJEU) accepted that the measure was not an EU act, so refused to review its legality. ${ }^{64}$ The CJEU also refused to consider the applicability of fundamental rights in a "humanitarian visa" context, a case that offered the opportunity to catalyze significant changes in refugee containment. ${ }^{65}$

Also of concern is the apparent dilution in protection offered by the ECtHR, in particular as regards detention conditions. ${ }^{66}$ This has been read as creating a "green light" for detention on arrival, without needing to examine the necessity of the detention. ${ }^{67}$ The ECtHR has also ruled that confinement at a land border is not "detention," in contrast to a previous ruling on airport transit zones. ${ }^{68}$ This Grand Chamber ruling comes against the backdrop of eighteen interim orders to prevent starvation in these land border zones, as it appeared that the Hungarian authorities were engaged in a systematic practice of food deprivation. ${ }^{69}$ Also infused with the rhetoric of crisis is the Grand Chamber ruling in N.D. and N.T. v. Spain, ${ }^{70}$ providing a restrictive interpretation of the prohibition on collective expulsion at Spain's land border in Africa.

Yet, as the contributions to this Special Issue attest, all is not lost.

Scholarship on "backlash" reminds us there are diverse forms of resistance to international courts, ${ }^{71}$ and thus far, at least, the resistance to the European supranational courts has been limited. Nonetheless, it is difficult to read the ECtHR and CJEU jurisprudence on migrant and refugee rights since the "crisis" as anything other than a genuflection to political power. But, the fundamentals have held, in large part. None of the rulings referred to above signal a dilution of the core prohibitions, although their application to the facts seems deferential to governmental claims on "crisis." And, as this Special Issue explores, the two supranational courts are not alone. In contrast to N.D. and N.T. v. Spain, for example, the U.N. Committee on the Rights of the Child has already ruled on Spain's migration control practices around its "fence" in Ceuta and Melilla, in a manner

\footnotetext{
${ }^{63}$ Riots Break Out in Lesvos and Chios, GreEK CiTY Times (Feb. 25, 2020), https://greekcitytimes.com/2020/02/25/riotsbreak-out-in-lesvos-and-chios54828/.

${ }^{64}$ N.F., N.G., and N.M. v. European Council, Case T-192/16 and ors.

${ }^{65}$ Case C-638/16, X \& X v. Belgium (Mar. 7, 2017), http://curia.europa.eu/.

${ }^{66}$ Several challenges concerning the detention and confinement conditions on the Greek islands were held not to violate Article 3 ECHR, in particular where detention was for periods deemed "short," of ca. one month.

${ }^{67}$ Tasos Kokkinidis, European Court Gives Greece Go-Ahead for Migrant Detention Centers, GreEK RePORTER (Feb. 19, 2020), https://greece.greekreporter.com/2020/02/19/european-court-gives-greece-go-ahead-for-migrant-detention-centers/.

${ }^{68}$ Ilias and Ahmed v. Hungary [GC], App. No. 47287/15 (Nov. 21, 2019), http://hudoc.echr.coe.int/eng?i=001-198760; cf. Amuur v. France, 22 E.H.R.R. 533 (1996).

${ }^{69}$ ECRE, Hungary: Continued Starvation Tactics Continued Interim Measures (Feb. 14, 2020), https://www.ecre.org/ hungary-continued-starvation-tactics-continued-interim-measures/.

${ }^{70}$ N.D. and N.T. v. Spain [GC], App. Nos. 86/75/15 and 8697/15 (Feb. 13, 2020), http://hudoc.echr.coe.int/eng?i=001201353.

${ }^{71}$ Mikael Madsen, Pola Cebulak \& Micha Wiebusch, Backlash against International Courts: Explaining the Forms and Patterns of Resistance to International Courts, 14 InTERNATIONAL JOURNAL OF LAW IN CONTEXT 197 (2018).
} 
that diffuses crisis rather than treating it as a ground for limiting rights, as Çalı, Costello, and Cunningham identify in their contribution to this Special Issue. ${ }^{72}$

At the international level, the crisis catalyzed two Compacts, reaffirming a commitment to refugee protection and responsibility sharing in the Global Compact on Refugees, and a range of commitment in the Global Compact for Safe, Orderly and Regular Migration. While the Compacts are not in themselves binding, they are an important international recognition that refugee and migrant protection are a matter of shared international responsibility. They may not in themselves dismantle refugee containment, but there is a possible constructive reading of them that emphasizes the importance of legalizing refugee flight and mobility. ${ }^{73}$ The Compacts depend on political will. In Europe, the realm of politics may be polarized, but the practical politics of solidarity and welcome continue. The "crisis" has been exploited by populists in many European states, but they are by no means in ascendance everywhere. The Italian Parliament has, for example, just decided to deny Salvini immunity on a charge of alleged "kidnapping" of migrants. ${ }^{74}$ Salvini was indicted due to an incident in July 2019, when 131 migrants were prevented from disembarking in an Italian port for almost a week. ${ }^{75}$

In short, and in colloquial language, one might simply admit that the availability of accountability in this field is very much up for grabs. This is part of what makes it such a fecund moment to take stock of all the major areas of law in which accountability can be imagined, and assess their promises and limitations. In doing so, the articles in this Special Issue also challenge received notions of accountability, granting it new and exciting meanings.

\section{Overview of the Special Issue}

Nikolas Feith Tan and Thomas Gammeltoft-Hansen offer "A Topographical Approach to Accountability for Human Rights Violations in Migration Control." This approach to accountability focuses on the site of violations from "a bird's-eye view" and aims to map accountability structures across diverse legal regimes, taking a broadened geographic lens. More specifically, they note that there is currently a "problematic dynamic between politics and law" in how politics responds to legal accountability, and that new approaches are needed. ${ }^{76}$ Notably, although they start with the "site" of violations, they trace wider contours of accountability to various sources. Focusing on Australia's site of offshore detention on Manus Island, Papua New Guinea, they note the variety of diverse attempts to establish, seek redress for, and ultimately bring the human rights violations there to an end. They consider a wide variety of actions: from various actions in Australia in both public and tort law; actions elsewhere in tort against private contractors profiting from the detention complex; to the Communication to the International Criminal Court containing a meticulous factual and legal analysis of Australian offshore detention as a crime against humanity. As they note, it was ultimately the Papua New Guinea Supreme Court that brought the arbitrary detention there to an end. ${ }^{77}$

\footnotetext{
${ }^{72}$ Başak Çall, Cathryn Costello \& Stewart Cunningham, Hard Protection through Soft Courts? Non-Refoulement before the United Nations Treaty Bodies, in this issue, referring to U.N. Comm. on the Rights of the Child, D.D. v. Spain, U.N. Doc. CRC/ C/80/D/4/2016 (Feb. 1, 2019).

${ }^{73}$ Cathryn Costello, Refugees and (Other) Migrants: Will the Global Compacts Ensure Safe Flight and Onward Mobility for Refugees?, 30 InT'L J. ReFugEe L. 643, 646 (2018).

${ }^{74}$ Senato Della Republica, Relazione della Giunta delle Elezioni e delle Immunità Parlamentari (Relatrice Stefani) sulla Domanda di Autorizzazione a Procedere in Giudizio ai Sensi Dell'Articolo 96 Della Costituzione Nei Confronti de Senatore Matteo Salvini Nella Sua Qualita di Ministro dell Interno Pro Tempore (Feb. 11, 2020), http://www.senato.it/service/PDF/PDFServer/BGT/1142649.pdf.

${ }^{75}$ See, e.g., Alessio Dellana, Italy's Senate Votes to Send Ex-Interior Minister Salvini to Trial over Alleged "Migrant Kidnapping," EuRoNews (Feb. 13, 2020), https://www.euronews.com/2020/02/12/salvini-faces-key-senate-vote-over-migrant-kidnappingallegations.

${ }^{76}$ Nikolas F. Tan \& Thomas Gammeltoft-Hansen, A Topographical Approach to Accountability for Human Rights Violations in Migration Control, in this issue.

${ }^{77}$ Namah v. Pato [2016] PGSC 13. See also Azadeh Dastyari \& Maria O’Sullivan, Not for Export: The Failure of Australia's Extraterritorial Processing Regime in Papua New Guinea and the Decision of the PNG Supreme Court in Namah (2016), 42(2) UNIV. L. REV. 308 (2016).
} 
The next contribution turns to the norm of non-refoulement. Basak Çall, Cathryn Costello, and Stewart Cunningham examine the decisions of four key UN Treaty Bodies (UNTBs), namely the Committee Against Torture, the Human Rights Committee, the Committee on the Elimination of Discrimination against Women, and the Committee on the Rights of the Child, on non-refoulement in their contribution "Hard Protection through Soft Courts? Non-Refoulement before the United Nations Treaty Bodies." By examining over five hundred decisions on non-refoulement, they offer a two-level comparison of the jurisprudence. First, the authors compare the interpretation of the Treaty Bodies inter se, and then with the European Court of Human Rights (ECtHR). The piece considers whether the overlapping authority of these UNTBs and "hard courts" risks fragmenting the norm, in a manner that could imperil compliance, or whether some norm consolidation is in evidence, together with healthy frictions that may enhance protection.

The question of accountability beyond territorial borders, and particularly at sea, has become central for migrants seeking to cross borders in an irregular manner, as well as their advocates. Three of our contributions address that question, looking at it from different perspectives. While focusing on maritime spaces, all three offer more general insights pertaining and contributing to the conversation on the nature of accountability and particularly of jurisdiction.

Akis Papastavridis's article sheds light on the relationship between "jurisdiction" as it figures in human rights law, and "jurisdiction" as it appears in the law of the sea. Underlying this separation is the premise that these are two distinguishable concepts. Papastavridis's fundamental contention is that when it comes to migrant interception, rescue, and disembarkation, categories specific to the law of the sea ought to inform human rights law, particularly Article 1 ECHR. It is thus both practically and theoretically untenable to address contemporary challenges placed before the ECtHR, pertaining to maritime interception, without a close look at law of the sea principles. Papastavridis highlights the possibility that law of the sea principles may dictate that a state may have jurisdiction over a vessel prior to obtaining direct control over it. Such may be the case when a Rescue Coordination Center (RCC) obtains information on a vessel in distress, but has not yet located it.

Beyond jurisdiction, law of the sea considerations may influence the analysis of whether a state has violated fundamental rights of migrants at sea. The most relevant here is Article 2 ECHR, the right to life. For example, in the case of a failed rescue attempt, Papastavridis contends that a due diligence requirement can be invoked under Article 2. The Search and Rescue (SAR) Convention of $1979^{78}$ requires states to operate RCCs. But has a state done that with due diligence, making sure that the relevant units are equipped and can communicate effectively? If not, a failed rescue attempt can lead to liability under Article 2. In Papastavridis's view, the "relevant rules of international law," that is, those of the law of the sea, "ought to influence the ECtHR's reasoning with respect both to the jurisdiction and the merits." The standard in his view, however, is not one of result.

One of the cases Papastavridis discusses is S.S. and others v. Italy, in which another contributor to our volume, Violeta Moreno-Lax, serves as lead counsel. Readers may therefore be interested in reviewing both contributions in conjunction. Moreno-Lax uses the applicants' arguments before the ECtHR as a springboard for developing her own theory of jurisdiction. Quite removed from Papastavridis's emphasis on the law of the sea, Moreno-Lax develops a "functional" approach to human rights jurisdiction, taking "extraterritorial maritime migration multi-actor interventions as a case in point." ${ }^{\text {79 }}$ She is careful in distinguishing her theory from the work of other authors, who have also espoused functional views of human rights jurisdiction.

Seemingly going against the grain of settled law, Moreno-Lax effectively denies any bright line between territorial and extraterritorial jurisdiction. For her, in both cases the decisive aspect

\footnotetext{
${ }^{78}$ International Convention on Maritime Search and Rescue, June 22, 1985, 1405 U.N.T.S. No. 23489.

${ }^{79}$ Violeta Moreno-Lax, The Architecture of Functional Jurisdiction: Unpacking Contactless Control-On Public Powers, S.S. and Others v. Italy, and the "Operational Model," in this issue.
} 
should be whether a certain policy is "predicated on the exercise of public powers," such powers, she believes, are unquestionably at issue within the thick nexus of Italian intervention, which she meticulously documents, in Libyan policies in the Mediterranean.

Beyond accountability for individual cases, three contributions take on questions regarding more systemic prevention of human rights violations across an entire policy. In this context, our contributors shed light on the role of the "due diligence" requirement in international law (already discussed by Papastavridis). The latter emerges from the Special Issue as a particularly fruitful concept for legal intervention, as well as for additional academic inquiry.

Vladislava Stoyanova's contribution on "The Right to Life Under the EU Charter and Cooperation with Third States to Combat Human Smuggling" asks whether the EU meets its positive obligations derived from the right to life in its external migration control actions. These practices ostensibly aim to reduce irregular migration by combatting smuggling, but may in reality increase its dangers. ${ }^{80}$ The institutional features of externalized migration controls-its extraterritoriality, multi-actor involvement, and informality, make identifying who is culpable for human rights violations more challenging. In addition, as Stoyanova admits, positive obligations leave the EU and its Member States wide discretion to assess what course of action is reasonable in order to vindicate the right to life. Nonetheless, by means of an insightful precis of the ECtHR caselaw on positive obligations, including in extraterritorial scenarios, ${ }^{81}$ she demonstrates that there is a positive obligation to assess the alternatives to current containment practices, including legalizing seeking asylum by issuing humanitarian visas.

For Carla Ferstman, states and international organizations "have due diligence obligations under human rights law to take all reasonable steps to ensure that the cooperation they provide does not result in human rights violations, even when the violations are perpetrated extraterritorially by third parties." Ferstman highlights that international organizations and some states have begun to adopt human rights due diligence policies to assess and mitigate the risks of cooperation in migration management. Using the examples of European Union and United Kingdom support to Libya, she shows that more often than not, these are lacking and problematic; due diligence policies aimed to mitigate violations of migrant rights have so far provided only superficial scrutiny and should be made more robust and transparent. And yet, Ferstman challenges and encourages lawyers to further engage with the due diligence framework, and put it to the test.

Daria Davitti's argument for a due diligence requirement is directed much more specifically to state obligations to regulate private enterprise, particularly private military and security companies (PMSCs). The normative framework Davitti adopts is that of the United Nations Guiding Principles on Business and Human Rights (2011). ${ }^{82}$ According to this framework, states must ensure that their legislation and regulations address the risk of business involvement in gross human rights violations. This requirement is heightened against the backdrop of conflict. While Libya and other migrant-producing countries have been sites for protracted conflict, these principles have so far not been systematically applied to violations in the context of migration. As Davitti explains: "Effective remedies would include, inter alia, providing access to the courts of the home state of the PMSC; and imposing civil and criminal liability on PMSC for their wrongful conduct." Failure to regulate, she argues, would result in a breach of the home state's obligation to protect from foreseeable PMSC's human rights abuse.

Two contributors examine specific EU agencies, EASO and Frontex. Notably, both contributions start from the premise that "normal" EU judicial review-that is, challenging the validity of these agencies' actions before the EU courts-is not a route to human rights accountability.

\footnotetext{
${ }^{80}$ Paolo Cuttitta et al., Various Actors: The Border Death Regime, in Border DeATHS: CAUSES, DyNAMICS AND Consequences of Migration-Related Mortality 35, 39 (Paolo Cuttitta \& Tamara Last eds., 2019).

${ }^{81}$ Tugar v. Italy, App. No. 22869/93 (Oct. 18, 1995) (inadmissible), http://hudoc.echr.coe.int/eng?i=001-2342.

${ }^{82}$ U.N. Human Rights Council, Guiding Principles on Business and Human Rights: Implementing the United Nations' Protect, Respect and Remedy Framework, U.N. Doc. A/17/31 (Mar. 21, 2011).
} 
Accordingly, they examine the role of the EU Ombudsman and the EU action for damages respectively.

Lilian Tsourdi's contribution turns to another EU actor with growing powers in this field, the European Asylum Support Office (EASO). Suggesting some of her conclusion, Tsourdi entitles her article "Holding the European Asylum Support Office Accountable for its role in Asylum Decision Making: Mission Impossible?” EASO has gradually moved to take on a role of directly deciding on asylum claims, albeit under the guise of "joint processing." As she demonstrates, these practices raise not only practical accountability challenges, but deep questions about tensions between "accountability" and "independence" in administrative decision-making. If accountability is understood in terms of political accountability to the Member States, then increasing EASO's accountability in that vein may imperil impartial, independent decision-making. If accountability is understood in terms of judicial review, Tsourdi notes, like Fink, that access to effective judicial protection against EASO in EU law is illusory. Against that backdrop, she turns to the role of the European Ombudsman and examines carefully two complaints brought against EASO's role in Greece, noting that the Ombudsman made important recommendations for reform of EASO.

Melanie Fink looks at the action for damages in EU law. In her previous work, Fink has examined Frontex in the round, ${ }^{83}$ and noted the challenges of subjecting its actions to EU fundamental rights accountability. The organization's impact on fundamental rights was clear, but its officially coordinating role meant that it generally regards only national officials as engaging in legally salient border controls. In her contribution to this Special Issue, "The Action for Damages as a Fundamental Rights Remedy: Holding Frontex Liable," she considers the extent to which tort liability of public authorities may be regarded as an apt remedy for fundamental rights violations. Turning to the EU doctrinal specifics, she demonstrates that if the action for damages is to work as a human rights remedy, the CJEU needs to broaden the range of conduct for which bodies may be held liable; loosen the "sufficiently serious breach" requirement; and adapt its take on positive obligations. She demonstrates that such doctrinal developments are appropriate, and could help close the accountability gap that persists when Frontex violates fundamental rights. She also argues for institutional reform within Frontex, in order to allow individuals to hold it to account.

The present Special Issue also cross-cuts legal disciplines, going beyond the usual sole focus on human rights law, including torts and international criminal law.

Alongside Fink's contribution, Gabrielle Holly too takes a look at tort law, focusing on the Australian example. While there is no direct cause of action for violations of human rights standards under Australian law, Australian courts have shown themselves to be receptive to tort claims with an extraterritorial dimension. Her article thus examines strategic litigation actions against the Australian government and the corporate contractors engaged in offshore detention, including Transfield and G4S. It provides an account of their achievements and their limitations. It focuses on two classes of strategic litigation: tort claims and claims seeking injunctive relief.

As Holly explains, these actions have vindicated the rights of those in offshore detention in specific ways. In some instances, they have even facilitated compensation for harms caused to detainees while in detention. Yet none have proved capable of challenging the underlying basis of the offshore detention regime, nor providing a foreseeable end to the detention of detainees. On occasion, litigation efforts have led to direct and immediate "backlash," when government responses to legal challenges have led to the introduction of more draconian policies. Generally, actions seeking injunctions requiring the Australian government to airlift individual detainees in offshore detention to Australia for medical treatment have been more successful than claims that have attempted to effect more systemic change.

Ioannis Kalpouzos provides an analysis of attempts to assert accountability for gross violations against migrants through the mechanisms of international criminal law. Like Moreno-Lax, his observations are firmly grounded in practical experience, and specifically on the complaint he

${ }^{83}$ Fink, supra note 7 , at $180-316$. 
had co-authored addressing Australian policies in Manus Island and Nauru. Against this backdrop, his article examines violence against migrants as part of state deterrence policies, coupled with efforts to use outsourcing to avoid responsibility and accountability for this violence. Rather than attempting to demonstrate that all such practices constitute international crimes, it asks how thinking about that violence through the prism of international criminal law may serve efforts to eliminate it.

The final contribution is that of Itamar Mann. While both Papastavridis and Moreno-Lax ask the question what obligations exist under the law towards migrants attempting to access European soil via maritime routes, Mann takes a different approach. Against the backdrop of far-reaching criminal and regulatory prohibitions that states have imposed on rescue operations, Mann focuses on the civil and political rights of would-be rescuers. Like Papastavridis, he seeks to consider the relationship between human rights law and the law of the sea. Yet his focus is on an entirely different aspect of the relationship between the two. By focusing on the rights of rescuers, he argues, advocates can also preserve the space in which migrants have opportunities to assert their own rights. Essentially, the goal is to ensure a condition in which the latter rights have a corresponding duty. The duty that volunteer rescuers have are, in the first instance, duties to rescue migrants in distress. But as Mann shows, these are not really severable from a more general duty to then grant them access to safe disembarkation, and ultimately access to asylum.

\section{Closing Accountability Gaps?}

The concise historical narrative above hopefully shed some light on how violations of migrants' and refugees' human rights have been normalized. Yet the burden is on us not only to show how accountability for these violations is lacking; we also aim to address this problem. Simply reorganizing the relationship between legal categories and disciplines will, of course, not generate political will for a wholesale reform of containment measures. But assuming the resources of such political will have not been depleted, the question is: How can law better be employed to realize such goals? Accountability for human rights violations is not sufficient to ensure justice in migration and for migrants and refugees, but it is an important place from which to start.

\section{Strategic Human Rights Litigation}

Several of our contributions stem from experiences in employing strategic litigation precisely in order to ameliorate accountability gaps. To clarify the term strategic litigation, consider a definition offered by the Open Society Justice Initiative, in a report dedicated to the topic: "Strategic human rights litigation" is "legal action in a court that is consciously aimed at achieving rights-related changes in law, policy, practice, and/or public awareness above and beyond relief for the named plaintiff(s)." ${ }^{\text {" }}$ Perhaps needless to say, the "change" referred to in this definition is rights-protective change.

Harold Koh's scholarship and experience of transnational public law litigation is pertinent. In a series of articles from the 1990s on, he reflected on experiences in the Sale litigation. ${ }^{85}$ In the ultimate judgement in Sale v. Haitian Centres Council, the U.S. Supreme Court upheld the U.S. Coastguard's offshore interdiction plan. ${ }^{86} \mathrm{Koh}$, as co-counsel for the Haitian asylum seekers, argued in line with refugee law orthodoxy that the U.S. Supreme Court misinterpreted the

\footnotetext{
${ }^{84}$ Open Society Justice Initiative, Strategic Litigation impacts: Insights From Global Experience 25 (2018).

${ }^{85}$ Harold H. Koh, Transnational Public Law Litigation, 100 YALE L.J. 2347 (1991); Harold H. Koh, America's Offshore Refugee Camps, 29 U. Rich. L. Rev. 139 (1994); Harold H. Koh, Why Do Nations Obey International Law?, 106 YALE L.J. 2599 (1997); Harold H. Koh, How Is International Human Rights Law Enforced?, 74 InD. L.J. 1397 (1999); Harold H. Koh, Transnational Legal Process, 75 Neb. L. Rev. 181, 184 (1996); Harold H. Koh, Why Transnational Law Matters, 24 Penn ST. InT'L L. Rev. 745 (2006). For an illuminating recent historical analysis of the litigation surrounding the Haitian offshore detention program, see JefFrey S. Kahn, Islands of Sovereignty: Haitian Migration and the Borders of Empire (2019).

${ }^{86}$ Sale v. Haitian Centers Council, 509 U.S. 155 (1993).
} 
Refugee Convention. He urged a program of litigation across international and domestic courts, envisaging that foreign and international decisions would gradually "correct" the mistake in a way, and ultimately lead the U.S. Supreme Court to turn in a more protective direction. ${ }^{87}$ A significant vindication of this approach was seemingly achieved at the European Court of Human Rights, in Hirsi and Others v. Italy, two decades after the Sale case (2012). ${ }^{88}$ Justice Pinto De Albuquerque, in his concurrence, cited in support Justice Harry Blackmun's minority opinion in Sale, paying tribute to his courageous stance in upholding the Refugee Convention. ${ }^{89}$

Yet the story of strategic litigation across those years was a complicated one. In 2013, Mann published a critique of transnational human rights litigation in which he showed that courts providing protective interpretations of refugee law often inadvertently became engines of externalization: The result was that executive branches further carried their action beyond court jurisdiction, bifurcating it from judicial review. ${ }^{90}$ Similarly, Gammeltoft-Hansen and James Hathaway observed a "cat-and-mouse game" between policy developments, and legal accountability, with the law catching up as practices are developed to escape accountability. ${ }^{91}$ Legal accountability, it seemed, often pushes practices further into the margins and shadows. Costello has also reflected on the "Pyrrhic Perils and Painstaking Progress" of strategic litigation in this field. ${ }^{92}$ Her experience includes providing expert affidavits in Canadian litigation, where practices now widespread in European asylum systems were successfully constitutionally challenged. ${ }^{93}$ In his recent monograph, Moritz Baumgärtel argues that strategic litigation in this field suffers from considerable limitations. These include a deficit in professional legitimacy from the judicial bench and the bar, and democratic legitimacy from the public at large. ${ }^{94}$

As described above, Gammeltoft-Hansen returns to this conundrum in his present article with Tan. Where do they stand, in their latest iteration, in the debate about the advantages and limitations of strategic litigation? Theirs is not a one-sided picture. It is surely not Koh's old vision of incremental progressive change, constantly expanding toward more protection. But it is also not the point of view Mann articulated, in which there's a danger that a kind of "negative dialectics" pushes protections lower and lower down the scale. ${ }^{95}$ The truth seems to be much more messywith opportunities opened and closed in a hardly predictable way, and outcomes that similarly retain an element of surprise. If anything, theirs is a call for opportunism in strategic litigation. Rather than searching for foundational legal truths, we read them as calling for a thoroughly pragmatist program.

Such an opportunism needs to keep an eye open on reality. Valuable, in that regard, are empirical studies that can measure success and failure in judicial bodies in a more-or-less scientific way. The one quasi-empirical contribution we have by Çalı, Cunningham, and Costello, can therefore be usefully joined with Gammeltoft-Hansen and Tan's "topographic" approach: It reveals that right at the center of the human rights system, the United Nations Treaty Bodies are much more effective enforcers than many of us may appreciate. These "soft" courts do not provide legally binding remedies, but when it comes to non-refoulement cases, it appears that their jurisprudence is serious and impactful. The non-binding nature may cause some strategic litigators to look at

\footnotetext{
${ }^{87} \mathrm{Koh}$ (1999) supra note 85, at 1406 (discussing transnational legal process as leading to "internalization" of international law).

${ }^{88}$ Hirsi Jamaa and Others v. Italy, App. No. 27765/09 (Feb. 23, 2012), http://hudoc.echr.coe.int/eng?i=001-109231.

${ }^{89} \mathrm{Id}$. at 80 .

${ }^{90}$ Itamar Mann, Dialectic of Transnationalism: Unauthorized Migration and Human Rights, 1993-2013, 54(2) HARV. INT'L. L.J. 315 (2013).

${ }^{91}$ Thomas Gammeltoft-Hansen \& James C. Hathaway, Non-Refoulement in a World of Cooperative Deterrence, 53 ColuM. J. Transnat'L L. 235, 246 (2015).

${ }^{92}$ Cathryn Costello, Strategic Litigation to Vindicate the Rights of Refugees and Migrants: Pyrrhic Perils and Painstaking Progress, in Legal Cases that Changed Ireland (Ivana Bacik \& Mary Rogan eds., 2016).

${ }^{93}$ Discussed in Costello, supra note 6.

${ }^{94}$ BAUMGÄRTEL, supra note 39 , at 125 .

${ }^{95}$ MANN, supra note 19 , at 364 .
} 
these "courts" with some suspicion when compared to domestic or "real" supranational courts such as the ECtHR or the CJEU. Perhaps better to think again.

The pragmatist approach Gammeltoft-Hansen and Tan take is very much in tension with the approach that emerges from a contribution that is directly based on experience in strategic litigation. Violeta Moreno-Lax has developed over the years her theory of extraterritorial jurisdiction, including in her 2017 monograph. ${ }^{96}$ Equipped with a sophisticated doctrinal toolkit, she represented litigants bringing a case before the ECtHR, aiming to challenge the practices the Italian government had developed since 2012 to escape accountability, following Hirsi. ${ }^{97}$ In her contribution to the Special Issue, she articulates the theoretical and normative grounding of her "functional" theory of jurisdiction. Far from any sort of pragmatism, her tenor is foundationalist, and owes its intellectual roots to theories of teleological interpretation, such as Dworkin's. ${ }^{98}$ In other words, hers is an ambition to spell out what is the right legal answer to the problem of extraterritorial migration controls, exposing normative truth in the realm of human rights.

From Moreno-Lax's perspective, we may imagine, a critique towards the more opportunist approach is that it ultimately may be self-defeating. If you don't take yourself seriously, why should others, including courts, do so? From the more pragmatist perspective, a possible critique of Moreno-Lax's doctrinal normativism is that it may leave little room for political processes. What is the role of participatory politics, if courts ultimately have the role of distinguishing right from wrong? And what do we do with the pattern of backlash we have seen post-2015, and the very real chance that it could be exacerbated? For readers who are also human rights lawyers, it might be interesting to locate yourselves between these two different poles.

\section{The Role of International Criminal Law}

Another contribution that comes directly out of experience with strategic litigation is that of Kalpouzos. Like Moreno-Lax, Kalpouzos takes the Special Issue as an opportunity to look back at his involvement in a specific case. Yet in his case, rather than a traditional human rights claim, at issue is an attempt to trigger an international criminal investigation. Five years back, Kalpouzos began his work on international criminal accountability for the violation of migrant rights in the Greek context. ${ }^{99}$ He examined policies in Greek detention centers, where irregular migrants, many refugees, were held in overcrowded, poor conditions. Together with Mann, he tried to impose accountability not only on Greece, but importantly also the Frontex officers deployed in Greece, whose work was rather insulated from legal scrutiny. ${ }^{100}$ Yet as mentioned above, in the contribution to this Special Issue he examines a case that sought to implicate potential Australian agents, for crimes against migrants on Nauru and Papua New Guinea. ${ }^{101}$

International criminal law is not usually thought of in this context. True, the forced displacement of populations is quite a "traditional" war crime, associated among other historical precedents with Nazi policies, which international criminal law had ostensibly risen to eradicate. But interpretations like Chetail's, cited above, in which the deportation in the normal run of migration control are examined as a possible crime against humanity are relatively novel. ${ }^{102}$ It is precisely the

\footnotetext{
${ }^{96}$ Moreno-LaX, supra note 18.

${ }^{97}$ See also Annick Pijneburg, From Italian Pushbacks to Libyan Pullbacks: Is Hirsi 2.0 in the Making in Strasbourg?, 20(4) EUR. J. MigRation \& L. 396 (2018).

${ }^{98}$ See, e.g., RONALD DWORKIN, LAw's EMPIRE (1986).

${ }^{99} \mathrm{See}$ Ioannis Kalpouzos \& Itamar Mann, Banal Crimes Against Humanity: The Case of Asylum Seekers in Greece, 16(2) Melb. J. INT'L. L. 1 (2015).

${ }^{100} I d$. at 3.

${ }^{101}$ See complaint available here: https://www.glanlaw.org/single-post/2017/02/13/Communication-made-to-InternationalCriminal-Court-requesting-investigation-of-Australia-and-corporate-contractors.

${ }^{102}$ Vincent Chetail, Is There Any Blood on My Hands? Deportation as a Crime of International Law, 29(3) LEIDEN J. INT'L L. 917 (2016).
} 
sense that accountability is not available anywhere else-that we are confronting entrenched "impunity" - that has invited their development. ${ }^{103}$

In this regard, international criminal law may be a discipline especially designed to deal with the problem of accountability, which we seek to confront here. Extreme forms of border violence present a perplexing reality. On the one hand, we have ample evidence, both forensic and testimonial, that human degradation is taking place on a grand scale. Kalpouzos thus opens his article with a quotation from author Behrouz Boochani, a former detainee in Australia's offshore system who has called the Australian policy criminal, a "crime against humanity," for which Australian politicians must and will be held accountable, a crime that reflects "the deepest form of violence in the world." ${ }^{104}$ On the other hand, there is simply no court to which the victims can turn with an appeal for an effective remedy. When domestic law fails to provide remedies to the victims of the most egregious of crimes, we are often told, there remains a seat of justice in The Hague. ${ }^{105}$

As recounted above, the hope anti-impunity rhetoric may kindle ran up against the wall of a restrictive interpretation of the relevant instrument, the Rome Statute. The Court wrote to Kalpouzos and his team that their submission did not provide the "contextual element" of the crime against humanity definition: They failed to show that the prohibited acts occur within the context of an "attack." Far from being naïve about international criminal law's capacity to simply fill in global gaps in accountability, Kalpouzos stresses instead that such an international criminal framing may still have an "expressivist" value: "The law declares or creates a 'punitive solidarity,' which, by identifying what and who is bad, contributes to the coherence of the members of a society. The ambition of ICL has been even greater, constructing such solidarity at a global level, and on the basis of purportedly universal values. Through and beyond retribution and deterrence, ICL powerfully evokes and unleashes an expressivist force."106

In full disclosure, one of us co-authored the complaint, and the other commented on it early on in its launch event. ${ }^{107}$ From our perspective, we therefore allow ourselves to speculate that international criminal law may still be more helpful than initially meets the eye (when reading the ICC's finding of its own lack of jurisdiction); even more helpful in closing accountability gaps than any exclusive emphasis on expressivism may suggest.

As Koh anticipated back in the 1990s, strategic litigation does sometimes have influence across very different kinds of forums. Thus, Gabrielle Holly stresses that the crime against humanity claim contributed to the efforts to establish accountability for the same wrongs through the procedural avenue of a domestic class action. As she explains, "two recent class actions have attempted to translate these alleged international crimes into negligence claims: Kamasaee $v$. Commonwealth of Australia and AUB19 v. Commonwealth."108 The first "ultimately settled for AUD70 million plus costs, considered to be the largest human rights class action settlement in Australian history. In proceedings on March 27, 2018, it was reported that about $\$ 67$ million of the $\$ 70$ million had been distributed to all but 73 of the 1,695 claimants." ${ }^{\prime 109}$ Holly is rightfully uncomfortable that the settlement "was agreed without admission of liability, and many of the

\footnotetext{
${ }^{103}$ Mann, supra note 12 .

${ }^{104}$ See, among many, Behrouz Boochani's comment that “Australia cannot ignore the human crisis in Manus and Nauru. The situation is getting worse day by day, it is a crime against humanity and violation of human rights. I wonder why the international humanitarian organization are silent in the face of these crimes." TwITTER (May 26, 2019), https://twitter.com/ behrouzboochani/status/1132850690705854464.

${ }^{105} \mathrm{Cf}$. Itamar Mann, The Dual Foundation of Universal Jurisdiction: Towards a Jurisprudence for the "Court of Critique," 1(4) Transnat'L Leg. Theory 485, 487 (2010) (developing the notion of a “court of last resort").

${ }^{106}$ See Ioannis Kalpouzos, International Criminal Law and the Violence against Migrants, in this issue. Cf. Barrie Sander, The Expressive Turn in International Criminal Law: A Field in Search of Meaning, 32(4) LEIDEN J. INT'L L. 851 (2019).

${ }^{107}$ At City University, London, February 13, 2017.

${ }^{108}$ Gabrielle Holly, Challenges to Australia's Offshore Detention Regime and the Limits of Strategic Tort Litigation, in this issue.

${ }^{109}$ Kamasaee v. Commonwealth of Australia \& Ors [2018] VSC 138.
} 
detainees who comprise the plaintiff group continue to live in a state of limbo," but such a step still seems like a step towards closing the accountability gap.

If this is not enough, she adds that the international criminal law campaigns (Kalpouzos writes of one of several) exerted reputational costs on the private actors involved in offshore detention: "As a result of these campaigns, the Australian government has found it difficult to secure reputable service providers to continue the provision of services to the Refugee Processing Centres ..."110 This relates to a final point, which is the centrality of private actors such as Ferrovial, Broadspectrum, and Paladin to the alleged criminal activities on Manus and Nauru.

Indeed, perhaps the corporate aspect of the international criminal angle to accountability has not yet been fully exhausted and remains to be fully explored by advocates. We note in this context that some of the companies involved in abusive offshore detention facilities are multinationals, not registered in Australia. Their actions may accrue criminal liability on the level of domestic law, in their countries of registration. Though challenging, the potential of international criminal prosecution under the doctrine of universal jurisdiction too is still to be fully explored. In such cases, private providers of services seem like vulnerable targets, not least because of their exposure to reputational costs that come with criminal investigations and sometime even with complaints. The transnational criminal law campaign has not yet run its full course.

\section{Tort Claims}

Be that as it may, seeking accountability solely through international criminal law is unlikely to end containment violations. International criminal law is already weak, in particular when the conduct of powerful states is impugned. Although multiple investigations are ongoing against agents of such states, every time the interests of such a state are implicated, international criminal law complaints have so far come to nothing. Which suggests another, more fundamental aspect of the settlement in the class action in Kamasaee. International criminal campaigns against powerful actors, more often not, end with no remedy in hand. Tort claims, on the other hand, can exert accountability by ordering the transfer of monetary compensation from the wrongdoer to the victim. Immediately, some may baulk at the notion of damages as an effective human rights remedy. Indeed, non-refoulement, rhetorically at least, is based on the notion that the harm to be prevent is irreparable, so no ex-post remedy will undo the damage. However, damages awards are part of human rights systems (although their potential to change state behavior has been questioned). ${ }^{111}$

This emphasis on material gains for the victims, which tort law seems to promise, is highlighted against Karen Engle's critique of the human rights movement's turn to criminal law. ${ }^{12}$ The impetus to punish, argue Engle and others, has diverted the attention of the human rights movement from the structural conditions in which violations emerge to begin with. Further, there is a certain kind of complicity between a human rights movement focused on punishment and the economic order that generates global inequality. ${ }^{113}$ Among other responses, Engle calls upon lawyers seeking to ameliorate social wrongs to pay greater attention to legal vocabularies directly engaged in redistribution: tax law, property law, and torts. ${ }^{114}$ Fink, who also writes about tort law, joins Holly in trying to fill this gap.

What we have learned however from working with these authors, is that private law provides no silver bullet. As Holly emphasizes, the economic remedy did not put an end to the structural

\footnotetext{
${ }^{110}$ Holly, supra note 108.

${ }^{111}$ Veronica Fikfak, Changing State Behaviour: Damages before the European Court of Human Rights, 29(4) EUR. J. INT'L L. 1091 (2018).

${ }^{112}$ Karen Engle, Anti-Impunity and the Turn to Criminal Law in Human Rights, 100 Cornell L. Rev. 1069 (2015). See also Anti-Impunity and the Human Rights Agenda (Karen Engle, Zinaida Miller \& DM Davis eds., 2016).

${ }^{113}$ See Samuel Moyn, Anti-Impunity as Deflection of Argument, in ANTI-IMPUNITY AND THE HuMAN RigHTS AGENDA 68, 69 (Karen Engle, Zinaida Miller \& DM Davis, eds., 2016).

${ }^{114}$ Engle, supra note 112 , at 1123 .
} 
issues offshore detention raises. The very fact Kamasaee was settled meant that underlying matters of Australian liability were not decided: "[T]he settlement means that there is still no clarity regarding the legal limits on how Australia is entitled to conduct its offshore detention centers, and what its corporate contractors may do to facilitate its policy." 115 Similarly, the case did not remove "the veil of secrecy that remains draped over the offshore detention centers." 116 There is a certain residue of structural violence in eschewing accountability, and a massive lack of transparency, which tort litigation may be amenable to.

\section{Positive Obligations}

Discussing Moreno-Lax, we have noted the role the interpretation of substantive human rights norms may take in closing accountability gaps. The one doctrinal and interpretive tool that emerged from the Special Issue as potentially most promising is positive obligations. From this perspective, the crucial move would be to clarify that states have robust duties to act to prevent human rights violations, including those generated by their migration control actions at home and abroad. Given that the roots of migrant containment are deep, positive obligations are turned to as a way of prompting a fundamental rethink of the costs of containment.

Positive obligations, due diligence in particular, offer a way to cut across the public/private divide, and encourage, indeed require states to adopt appropriate regulatory systems to address risks, including risks that individuals take on when they act unlawfully. Our authors direct such robust duties towards states in order to ensure rescue and disembarkation in a port of safety (Papastavridis); prevent European actors from contributing to egregious human rights violations in Libya (Ferstman); oversee the actions of private military firms when it comes to fulfilling contracts in Libya (Davitti); and extinguishing the negative influence that anti-smuggling laws have towards asylum seeking (Stoyanova).

How should one understand this apparent frontier in the common objective of better enforcing migrant rights? One way to look at them is by considering their precise legal source. Positive human rights obligations can derive from original interpretations of human rights instruments, such as the ICCPR, ECHR and EUCFR. Indeed, the Istanbul Convention is expressly framed in terms of due diligence obligations, ${ }^{117}$ of particular relevance in migration control. Positive obligations may also derive from the interpretation of treaties that are not ordinarily thought of as part of the human rights machinery. Papastavridis focuses on the Search and Rescue Convention. Human rights due diligence also emerges in domestic and regional law. For example, Ferstman examines EU and UK administrative law; or they can stem from the provisions of soft law instruments, as Davitti demonstrates looking at United Nations Guiding Principles on Business and Human Rights.

As Stoyanova highlights, positive obligations are often indeterminate, or at least in need of greater specification. Under the ECHR, they have generally been honed to impose fairly general obligations to avoid violations, and much more specific obligations as regards the investigation and remedying of violations. If courts impose positive obligations with too high a degree of specificity, they may be accused of overstepping the boundaries of the judicial role. Given the contemporary politics of backlash, courts may be wary in this context. However, due diligence obligations are not only the stuff of high-profile supranational cases. Ferstman in her article suggests a method of what might be called comparative positive obligations studies. Comparing the EU and the UK frameworks in terms of their practical application, including procedural safeguards such as transparency, she suggests broader insights on how advocates should employ positive obligations. Rather than focusing on the legal interpretation of such duties, her approach

\footnotetext{
${ }^{115}$ Holly, supra note 108 .

${ }^{116} I d$.

${ }^{117}$ Council of Europe Convention on Preventing and Combating Violence against Women and Domestic Violence, May 11, 2011, C.E.T.S. No. 210 , art. 5.
} 
demonstrates the importance of examining the institutionalization of these duties in policy making and implementation.

This leads us to reflecting generally on whether positive obligations are ever practical and effective. We may expect the answer varies across different systems. Further comparison would be a fruitful avenue for exploration (a) in order to reach a granular understanding of their entrenchment within concrete institutions; and (b) how this institutionalization impacts effectiveness. Positive obligations may amount to powerful safeguards to avoid human rights violations, or else may present an exercise in bureaucratic box-ticking. Much will depend on the legal source that imposes the positive obligation, and its institutionalization, including whether it creates processes that are accessible, transparent, and reviewable.

\section{Direct Action}

But what if the rights that law grants to migrants do not suffice to "close the accountability gap" that migrants have suffered from? Mann made precisely this suggestion a couple of years back, in a paper entitled "Maritime Legal Black Holes: Migration and Rightlessness in International Law." The focus there was on drownings in the Mediterranean, and since its publication, that tragedy has only persisted. According to IOM's Missing Migrants Project, as of February 2020 nearly 20,000 "migrant fatalities" have been recorded in the Mediterranean, nearly $60 \%$ of the world total. ${ }^{118}$ More than 4,000 such deaths have been recorded in the last two years alone. ${ }^{119}$

The very persistence of this phenomenon reflects the failure of legal accountability in protecting migrants. To put the point in terms of the two questions we have proposed at the outset, the conclusion may be the following: The fact that accountability for human rights violations in the context of migration control is often lacking, is not due to a misunderstanding of the mechanisms that may provide such accountability. It is, rather, because no such methods of accountability exist in extant law. The studies introduced above suggest invaluable tools to do the best one can, with law, to eliminate a structural absence of accountability. But even after a cross-cutting integration of legal disciplines, the five features of the accountability deficit enumerated at the outset may leave a remainder at the heart of the system.

The example of drowning is illustrative, but the underlying issue does not apply only to migrants at sea. It may apply every time people suffer horrible abuses that are not, legally, in violation of their rights (as a matter of lex lata). Think of a migrant who has managed to flee dire poverty and suffers from a medical condition for which treatment is not available in her country of origin. She may well be deported due to the limited scope of the norm of non-refoulement. ${ }^{120}$ After her deportation, she may perish; but its conditions may render questionable any attempt to lay the blame for lack of effective medical care on her state.

The people are rendered rightless by the way international law distributes responsibility among its subjects, particularly states and private actors. Such rightlessness goes to the roots of the current conditions that set the backdrop for this Special Issue. Carrier sanctions, for example, redistribute responsibility between states and private actors to establish a rightlessness that has not been effectively challenged. Since the 1980s, neoliberal law has gradually transferred the public authority of migration control to private entities, solidifying spaces of entrenched, hard-wired rightlessness.

It is in this context that the onus to respect and protect human rights has also been shifted to private actors. Churches, charities, civil society actors, have thus employed direct action to change the conditions in which law is applied. If an accountability deficit is hard-wired into international

\footnotetext{
${ }^{118}$ Migration Deaths and Disappearances, Migration Data PorTal (Feb. 5, 2020), https://migrationdataportal.org/ themes/migrant-deaths-and-disappearances.

${ }^{119}$ Total of Deaths Recorded in Mediterranean from 01 January to 02 March, Missing MigRANTs, https://missingmigrants. iom.int/region/mediterranean.

${ }^{120} \mathrm{Cf}$. N. v. United Kingdom [GC], 47 E.H.R.R. 39 (2008). For an illuminating analysis and critique, see Virginia Mantouvalou, $N v$ UK: No Duty to Rescue the Nearby Needy?, 72(5) M.L.R. 815 (2009).
} 
law, such direct action may be a necessary final modality to consider for closing the accountability gap. Once again, the central Mediterranean is illustrative of how this may work.

But how does one "change the conditions in which law is applied"? One form of direct action that can be conceptualized as a form of self-help enforcement from below is simply crossing the border. If that is not possible, one might otherwise place oneself under the jurisdiction of a party that is obligated and able to respect the rights of everyone there. ${ }^{121}$ Migrant protests too have been conceptualized as a form of civil disobedience. ${ }^{122}$

In a yet unpublished paper, Frédéric Mégret put migrant-protective direct action in the wide context of a tradition in which "non-state groups 'take international law in their own hands' and seek to implement it from below, suo sponte and in the name of an exalted vision of international justice." ${ }^{123}$ He thus beautifully put the ways in which rescue activists participate in such direct action, precisely where an accountability deficit seems intractable: "Migrant rescue operations ... subtly refound international law. Specifically, they include two distinct operations. First, the rescue of bare life indeed, a pure human rights encounter. Second, beyond the attempt to have states honor their promise of asylum to the persecuted, a form of assistance to the completion of a project of asylum-seeking, at times barely distinguishable from projects of emigration." 124 If the five elements we have enumerated as causes for the accountability deficit now seem solidified to the extreme, such acts thus help to not only envision but also put into practice an international law that refuses to accept them as faits accomplis.

In his contribution to this volume, Mann borrows from analytic jurisprudence, to argue that such actions should be recognized as part and parcel of the enforcement of international law. As he writes, they are implicit in a system that otherwise creates gaps where governmental power can go unchecked. And they offer the only mechanism that can truly seek to eliminate the spaces of rightlessness that have appeared as "maritime legal black holes": "It is thus not human rights tribunals or committees, or the international criminal court, that has the primary responsibility to provide accountability where no other accountability exists. It is the responsibility of rights-bearing subjects of the law." 125

This understanding of direct action blurs the difference between civil disobedience and what might be called civil obedience. After all, migrants and activists who claim to be protecting the human rights of others often call on the law's protection in so doing. And courts are heeding that call: Indeed, there is now at least a trio of high profile cases where individuals have successfully asserted their right to act in solidarity with migrants, albeit in different legal contexts. ${ }^{126}$ The Appullonapa ${ }^{127}$ ruling of the Canadian Supreme Court effectively limited the overbreadth of smuggling prohibitions, preventing the criminalization of acts of mutual, family, and humanitarian assistance to enter Canada irregularly. The French Conseil constitutionnel ruled in favor of the right of Cédric Herrou ${ }^{128}$ to act in 'fraternité' with those seeking refuge in France. ${ }^{129}$ And most recently, the Italian Supreme Court of Cassation vindicated the actions of Carola Rackete, the

\footnotetext{
${ }^{121}$ MANN, supra note 19 (esp. ch. 2).

${ }^{122}$ Frédéric Mégret, Civil Disobedience and International Law: Sketch for a Theoretical Argument, 46 CAN. Y.B.I.L. 143 (2009).

${ }^{123}$ Frédéric Mégret, Activists on the High Seas: Reinventing International Law from the Mare Liberum? (unpublished paper, on file with the authors).

${ }^{124} I d$.

${ }^{125}$ Itamar Mann, The Right to Perform Rescue at Sea: Jurisprudence and Drowning, in this issue.

${ }^{126}$ Frequently, individuals assisting migrants fall foul of overbroad smuggling prohibitions and other criminal prohibitions on assisting migrants with irregular entry or stay. See further Rachel Landry, The 'Humanitarian Smuggling' of Refugees: Criminal Offence or Moral Obligation?, (RSC Working Paper Series No. 119, 2016) available at https://www.rsc.ox.ac.uk/ publications/the-humanitarian-smuggling-of-refugees-criminal-offence-or-moral-obligation

${ }^{127}$ R. v. Appulonapa [2015] SCC 59 (Nov. 27, 2015).

${ }^{128}$ Conseil constitutionnel [CC] [Constitutional Court] decision No. 2018-717/718 July 6, 2018, J.O. 155 (Fr.).

${ }^{129}$ See further Jennifer Allsopp \& Cathryn Costello, Smuggling Prohibitions vs. Duties of Humanity, ReTHINKING REFUGE (June 20, 2019), https://www.rethinkingrefuge.org/articles/smuggling-prohibitions-vs.-duties-of-humanity.
} 
captain of the NGO vessel Sea Watch 3. It not only found that her arrest was illegal. Perhaps more importantly, it advanced a clarification of the international law of the sea: The obligation to render assistance at sea includes the obligation to disembark rescuees in a "port of safety." 130 These judgments illustrate that on occasion, it is by breaking the law and taking action to protect human rights, that the law in turn is transformed.

\section{E. New Accountability Challenges}

As we finalize this Special Issue, news had arrived of the ruling in Carola Rackete's case, just as it appeared that the Greek government was planning to use force to repel those arriving at its borders seeking protection. A legal victory followed by an attempt to legitimate border violence: The concurrent events follow the familiar pattern evoked throughout this introduction. What we have is a struggle all the way down, with no ability to make optimistic predictions, but also no reason to lose hope for better outcomes.

Meanwhile, an even more elusive form of migration control is emerging. Human rights scholar Eyal Weizman recently wrote of his 'algorithmic' refusal of entry to the U.S. ${ }^{131}$ Poignantly, Weizman had been on his way to Miami, to launch a new project directly pertinent to questions of legal accountability: an investigation "into human rights violations at the Homestead detention centre in Florida, where migrant children have been held in what activists describe as 'regimented, austere and inhumane conditions."'132 His group, Forensic Architecture, has developed innovative methods to document and reconstruct human rights violations in order to establish accountability in migration control. Indeed, Forensic Oceanography, a project run by Charles Heller and Lorenzo Pezzani that has begun as part of Weizman's laboratory, conducted an investigation on which the case discussed by Moreno-Lax in her contribution is based. ${ }^{133}$ It has also supported the international criminal complaint about which Kalpouzos writes. Their work has been indispensable in shedding light on facts that would otherwise remain out of view.

Accordingly, we close with a new accountability challenge. States are outsourcing their migration control decisions not only to private entities, but to machines. As Weizman acknowledges, algorithmic visa denials are now routine. Fleur Johns has explained this is a recent discussion of refugee processing: "The very experience of characterizing the world's conditions, and of exercising power to govern, make legally significant decisions, and conduct juridical relationships on the global plane are under revision in the face of automation, especially with the growing prevalence of machine learning." 134 Thankfully, some scholars have begun the work to imagine how accountability may be institutionalized in this context. ${ }^{135}$

By way of conclusion, readers of this Special Issue should keep in mind that the contemporary discussion of legal accountability is couched between these two material conditions: On the one hand, understanding violations depends on information and its framing. On the other, legal

\footnotetext{
${ }^{130}$ Cass. Pen., terz. sez., 20 febbraio 2020, n. 30036/2019 (It.). See further Stefano Zirulia, La Cassazione sul caso Sea Watch: le motivazioni sull'illegittimità dell'arresto di Carola Rackete, SISTEMA PENALE (Feb. 24, 2020), https://www.sistemapenale.it/it/ scheda/cassazione-sea-watch-illegittimo-larresto-di-carola-rackete.

131"In my interview the officer informed me that my authorisation to travel had been revoked because the 'algorithm' had identified a security threat ... it could be something I was involved in, people I am or was in contact with, places to which I had travelled ... or a certain pattern of relations among these things." Eyal Weizman, The Algorithm is Watching You, LRB BLOG (Feb. 19, 2020), https://www.lrb.co.uk/blog/2020/february/the-algorithm-is-watching-you.

${ }^{132} I d$.

${ }^{133}$ Charles Heller \& Lorenzo Pezzani, Mare Clausum: Italy and the EU's Undeclared Operation to Stem Migration ACROSS THE MEDiterRANEAN (2018), https://content.forensic-architecture.org/wp-content/uploads/2019/05/ 2018-05-07-FO-Mare-Clausum-full-EN.pdf.

${ }^{134}$ Fleur Johns, Data, Detection, and the Redistribution of the Sensible in International Law, 111(1) A.J.I.L. 1, 3 (2017).

${ }^{135}$ See also Petra Molnar \& Lex Gill, Bots at the Gate: A Human Rights Analysis of Automated DecisionMAKING In CANADA's Immigration AND RefugEe System (2018), https://citizenlab.ca/wp-content/uploads/2018/09/ IHRP-Automated-Systems-Report-Web-V2.pdf.
} 
processes are intrinsically concerned with applying rules to facts, to information. Any discussion of accountability for human rights violations is thus dependent on and inseparable from the work of establishing the facts - the work that human rights investigators and journalists often do in the background, and courts and human rights bodies do when adjudicating. Meanwhile, however, our conception of legal processes as applying law to facts, as a basic framework for accountability, might be in a gradual process of disappearing into the digital realm. States disempower themselves in order to dissipate accountability further. 